\title{
Quality criteria and evaluation: a measuring instrument for the German language area
}

\author{
U. Brok, T. Sporer. Catholic University Eichstätt-Ingolstadt, Germany \\ C. Leitzmann. Catholic University Eichstätt-Ingolstadt - State Network for Civil \\ Involvement in Bavaria, Germany
}

M. Schlegler, L. Müller. Frankfurt University of Applied Sciences, Germany

J. Sonnberger. University of Applied Sciences Augsburg, Germany

J. Derkau. University of Mannheim, Germany

\begin{abstract}
The University Network on Social Responsibility is a network of more than 40 universities in Germany and Austria established in 2009 that want to realise and expand their social responsibility by systematically promoting the civil society engagement of students, teachers, and other members of higher education, linking this with their educational mission and thus actively influencing society and contributing to the mutual transfer of knowledge. This can be done through the teaching-learning format of service learning (SL). In 2018, a workshop initiated a discussion between representatives of academia and civil society. The focus was the aspect of quality of SL. The group came up with ten different criteria which provide a frame of reference for the different manifestations of SL in the community. Based on these criteria, suitable procedures and instruments were developed to provide SL actors with orientation and suggestions for the implementation and evaluation of SL projects.
\end{abstract}

\section{Keywords}

Online questionnaire, research, quality development, service-learning.

Fecha de recepción: 24/XI/2021

Fecha de aceptación: 9/XII/2021

Brok, U., Leitzmann, C., Schlegler, M., Müller, L., Sonnberger, J., Derkau, J. y Sporer, T. (2021). Quality
criteria and evaluation: a measuring instrument for the German language area. RIDAS, Revista Iberoamericana de Aprendizaje Servicio, 12, 45-58. DOI10.1344/RIDAS2021.12.6 


\section{Criterios de calidad y evaluación: un instrumento de medición para el área de la lengua alemana}

\section{Resumen}

La Red Universitaria sobre Responsabilidad Social es una red de más de 40 universidades en Alemania y Austria, establecida en 2009, que desean realizar y expandir su responsabilidad social promoviendo sistemáticamente la participación de la sociedad civil de estudiantes, docentes y otros miembros universitarios, vinculando con su misión educativa para influir activamente en la sociedad y contribuir a la transferencia mutua de conocimientos. Ello se puede hacer a través del aprendizajeservicio (ApS). En 2018, un taller inició un debate entre representantes de la academia y la sociedad civil. El foco fue los aspectos de calidad del ApS. El grupo ideó diez criterios diferentes que proporcionan un marco de referencia para las diferentes manifestaciones de ApS en la comunidad. Con base en estos criterios, se desarrollaron procedimientos e instrumentos adecuados para proporcionar a los actores orientación y sugerencias para la implementación y evaluación de proyectos de ApS.

\section{Palabras clave}

Cuestionario, investigación, desarrollo de la calidad, aprendizaje-servicio. 


\section{Criteris de qualitat i avaluació: un instrument de mesura per a l'àrea de Ilengua alemanya}

\section{Resum}

La Xarxa Universitària sobre Responsabilitat Social és una xarxa de més de 40 universitats d'Alemanya i Àustria establerta el 2009 que volen fer realitat i ampliar la seva responsabilitat social promovent sistemàticament la participació a la societat civil d'estudiants, professors i altres membres universitaris, vinculant-ho amb la seva missió educativa per influir activament en la societat i contribuir a la transferència mútua de coneixements. L'aprenentatge servei (ApS) és una manera de fer-ho. El 2018, un taller va iniciar una discussió entre representants del món acadèmic i de la societat civil. El focus era analitzar els criteris de qualitat de l'ApS. El grup va plantejar deu criteris diferents que proporcionen un marc de referència per a les diferents manifestacions de l'ApS a la comunitat. A partir d'aquests criteris, es van desenvolupar procediments i instruments adequats per oferir als actors orientació i suggeriments per a la implementació i avaluació dels projectes d'ApS.

\section{Paraules clau}

Qüestionari, recerca, desenvolupament de la qualitat, aprenentatge servei. 


\section{Introduction}

The University Network on Social Responsibility (Hochschulnetzwerk Bildungdurch Verantwortung e.V) is an alliance of universities that has existed since 2009 and aims to strengthen the civic engagement of students, teachers, and other university staff. They acknowledge the encouragement and empowerment of personal and social responsibility as an essential educational mission. The aim of the network is to improve the quality of academic teaching as well as the mutual transfer of knowledge between university and community, thus making a specific contribution to promoting social interaction. In spring 2015, the university network - which more than 40 universities have joined institutionalized itself as an association (Hochschulnetzwerk Bildung durch Verantwortung, 2021).

Some of the initiatives of the network include conferences, political lobbying, and participation in working groups. Beyond that, the network provides information about conferences and events in a regular newsletter and informs about opportunities for participation. The main areas are service-learning in teacher training, research on service-learning, the university of the future, and the integration of refugees.

The Quality Working Group of the Network deals with the question 'What constitutes good service-learning?'. Together with the community, it has been working on quality criteria for service-learning (see also Mishal et al., 2021; RMC Research Corporation, 2008; Seifert, et al., 2012; Root \& Billig, 2008) and useful instruments for quality development since the summer of 2018. Its purpose is to give actors an orientation on how quality can be ensured and how quality assurance can be considered during planning, conception, and implementation. The quality criteria were completed in early 2019 and served as the basis for developing support tools (Hochschulnetzwerk Bildung durch Verantwortung/AG Qualität, 2019).

Since 2020, a subgroup has been working on the development of items for the evaluation of service-learning projects. This paper presents the results of the Quality Working Group: Based on the quality criteria for servicelearning, evaluation instruments for service-learning projects both for students, teachers, and partners are described, which are applied in Germany.

\section{Methodology}

The University Network on Social Responsibility set itself the goal of developing quality criteria that define an educational and scientific benchmark for the various manifestations of service-learning projects. In 2018, a workshop that focused on dialogue between higher education institutions and non-profit organizations kicked off a discussion between representatives from the scientific community and civil society which spanned several months. The focal point of this discussion was the quality of service-learning (see also 
Mishal et al., 2021; RMC Research Corporation, 2008; Seifert, et al., 2012; Root \& Billig, 2008).

The whole purpose of this series of conversations was to describe the various forms of service-learning as well as identify their unique features, and thereby highlight the exceptional potential of learning through engagement.

Ultimately, the group came up with ten different criteria that constitute a reference framework for the various manifestations of service-learning in the community, without making the definition too restrictive (Sonnenberger \& Leitzmann, 2020; Hochschulnetzwerk Bildung durch Verantwortung/AG Qualität, 2019). These quality criteria serve as a basis for future quality development and quality assurance activities in the field of service-learning. As table 1 shows, the quality criteria are based on a social need, define common goals with external partner organizations, guarantee an acquisition of skills, support students to learn and act outside of their own university and study environment, include a cooperation between the parties as well as student support, a quality development and evaluation, a reflection, an appreciation and recognition at the end of the course, and document that service-learning is structurally and content-wise integrated and linked to the learning goals of the course.

\section{RIDIS}

Table 1. Ten Criteria. A Reference Framework for Successful service-learning (Hochschulnetzwerk Bildung durchVerantwortung/AG Qualität, 2019).

\begin{tabular}{|c|c|}
\hline Criterion & Description \\
\hline 1. Societal need & $\begin{array}{l}\text { Projects and measures arise out of } \\
\text { real societal problems and } \\
\text { challenges and aim to provide the } \\
\text { individual, a group or society at } \\
\text { large with a specific benefit. }\end{array}$ \\
\hline 2. Defined goals & $\begin{array}{l}\text { All the parties involved define } \\
\text { common goals, work together in } \\
\text { an effort to achieve them and, } \\
\text { finally, assess whether the goals } \\
\text { have been achieved. }\end{array}$ \\
\hline $\begin{array}{l}\text { 3. Service-learning } \\
\text { is an Inherent } \\
\text { Aspect of the } \\
\text { Degree Course }\end{array}$ & $\begin{array}{l}\text { Service-learning is integrated into } \\
\text { the degree course in terms of } \\
\text { structure and content and is linked } \\
\text { to the learning objectives of the } \\
\text { degree course. }\end{array}$ \\
\hline $\begin{array}{l}\text { 4. Skills } \\
\text { Acquisition by } \\
\text { Students }\end{array}$ & $\begin{array}{c}\text { In service-learning, students } \\
\text { acquire personal, social, technical } \\
\text { and professional skills in } \\
\text { connection with the content and } \\
\text { didactic structure chosen by the } \\
\text { teaching staff and non-profit } \\
\text { organizations. }\end{array}$ \\
\hline $\begin{array}{l}\text { 5. Studying in } \\
\text { Foreign Living } \\
\text { Environments }\end{array}$ & $\begin{array}{c}\text { Student's study and take action } \\
\text { outside their own university and } \\
\text { study environment. }\end{array}$ \\
\hline $\begin{array}{l}\text { 6. Collaboration } \\
\text { between Parties } \\
\text { Involved }\end{array}$ & $\begin{array}{c}\text { All of the parties involved work } \\
\text { together to plan, prepare and } \\
\text { shape service-learning. }\end{array}$ \\
\hline 7. Reflection & $\begin{array}{c}\text { The parties involved reflect on } \\
\text { their service-learning experiences } \\
\text { with the aid of technical and } \\
\text { academic guidance. }\end{array}$ \\
\hline $\begin{array}{l}\text { 8. Student } \\
\text { supervision }\end{array}$ & $\begin{array}{l}\text { Students are provided with } \\
\text { support and supervision while they } \\
\text { are planning and executing } \\
\text { service-learning projects. }\end{array}$ \\
\hline $\begin{array}{l}\text { 9. Evaluation and } \\
\text { quality } \\
\text { development }\end{array}$ & $\begin{array}{l}\text { Service-learning projects include } \\
\text { evaluation measures, particularly } \\
\text { with regard to quality assurance } \\
\text { and development. }\end{array}$ \\
\hline $\begin{array}{l}\text { 10. Recognition and } \\
\text { appreciation }\end{array}$ & $\begin{array}{c}\text { In service-learning, the } \\
\text { commitment and performance of } \\
\text { the parties involved are } \\
\text { acknowledged and valued, } \\
\text { particularly on completion of } \\
\text { service-learning. }\end{array}$ \\
\hline
\end{tabular}

Source: own elaboration 
The first criterion Societal need describes that projects and measures arise out of real societal problems and challenges and aim to provide the individual, a group, or society at large with a specific benefit. Defined goals is the second criterion and means that all the parties involved define common goals, work together in an effort to achieve them, and, finally, assess whether the goals have been achieved. The third criterion Service-learning is an Inherent Aspect of the Degree Course outlines that service-learning is integrated into the degree course in terms of structure and content and is linked to the learning objectives of the degree course. Skills Acquisition by Students is the fourth criterion and specifies that in service-learning, students acquire personal, social, technical, and professional skills in connection with the content and didactic structure chosen by the teaching staff and non-profit organizations. Further, the fifth criterion Studying in Foreign Living

Environments also describes that Students study and take action outside their own university and study environments. Correspondingly, all the parties involved work together to plan, prepare, and shape service-learning, as the sixth criterion Collaboration between Parties Involved points out. Moreover, Reflections as the seventh criterion means that the parties involved reflect on their servicelearning experiences with the aid of technical and academic guidance. Simultaneously, Student supervision is important in the manner that students are provided with support and supervision while they are planning and executing service-learning projects. Service-learning projects include evaluation measures, particularly with regard to quality assurance and development like the ninth criterion (Evaluation and quality development) explains. Finally, Recognition and appreciation describes that in servicelearning, the commitment and performance of the parties involved are acknowledged and valued, particularly on completion of service-learning.

In a first step based on these criteria, suitable procedures and instruments were developed to provide servicelearning actors with orientation and suggestions for the implementation and evaluation of service-learning projects. Consequently, the criteria have been operationalized in items of online questionnaires for measuring instruments to evaluate servicelearning activities. For this purpose, first an extensive literature search for already existing instruments was conducted. Subsequently, the already existing items were assigned to the quality criteria. In joint discussions between researchers, teachers and representatives of civil society, the items were adapted and supplemented with regard to the target groups.

Subsequently, the items were discussed and finalized with a focus group consisting of representatives of the respective target group. The online questionnaires are available for different actors: partner organizations, students, and teachers, and are currently being validated. After a brief instruction, the participants of the survey rate their agreement with the realization of service-learning in a 
specific service-learning project on usually four-point Likert scales (from $1=$ "fully applies", $2=$ "rather applies", $3=$ "rather does not apply" to $4=$ "does not apply at all"). In addition, participants were able to report "I do not know".

The dimensions are analog to the quality criteria described above. A first version of the three questionnaires was revised in interviews with expert groups. The current version of the measurement instruments for teachers uses the operationalization below ${ }^{1}$.

1. Social need is operationalized by the following items (Furco et al., 2018; Hochschule Augsburg, 2019; Melchior, 1998):

"Der Aufgabenstellung im Projekt lag ein konkreter Bedarf zu Grunde."(The project task was based on a concrete need).

"Ich als Dozierende*r kenne den Kontext und die Bedürfnisse der Partner-Organisation."(As a lecturer, I know the context and the needs of the partner organization).

"Die Arbeit, die im Rahmen des Projekts geleistet wurde, hatte einen Mehrwert für die PartnerOrganisation." (The work done in the project had an added value for the partner organization).

"Die Arbeit, die im Rahmen des
Projekts geleistet wurde, hatte einen Mehrwert für die ServiceNehmenden." (The work done in the project had an added value for the service recipients).

2. Defined goals is operationalized by the following items (Cram, 1998; Hochschule Augsburg, 2019):

"Das Projekt hatte klar definierte Ziele." (The project had clearly defined goals).

"Die Projektziele wurden gemeinsam mit der PartnerOrganisation definiert. (The project goals were defined together with the partner organization).

"Die Projektziele wurden gemeinsam mit den ServiceNehmenden definiert." (The project goals were defined together with the service recipients).

"Die Projektziele wurden gemeinsam mit den Studierenden definiert." (The project goals were defined together with the students).

"Das Zusammenspiel zwischen Service-Aktivitäten und Kursinhalten wurde allen Projektbeteiligten verdeutlicht." (The correlation between service activities and course content was made clear to all project stakeholders).

"Die Ziele, Erwartungen und

\footnotetext{
${ }^{1}$ In the following, the German version of the questionnaire items is presented first, with an English translation in brackets.
} 
rechtlichen Fragen des Projekts wurden mit allen

Projektbeteiligten besprochen." (The goals, expectations, and legal issues of the project were discussed with all project stakeholders).

3. Service-learning is part of the degree program is operationalized by the following items (Furco et al., 2018; Hochschule Augsburg, 2019; Speck \& Backhaus-Maul, 2007):

"Es existieren feste Regelungen, Vereinbarungen oder Maßnahmen zur Einbindung von Service Learning in die Lehre an der Hochschule/Universität." (There are fixed regulations, agreements, or measures for the integration of service-learning into teaching at the college/university).

"Die Service Learning-Erfahrung der Studierenden unterstützte den akademischen Inhalt des Kurses." (The service-learning experience of the students supported the academic content of the course).

"Die Projektziele und die damit verbundenen Service-Aktivitäten passten zu den Lehr-/Lernzielen des Moduls." (The project objectives and associated service activities matched the teaching/learning objectives of the module).

4. Acquisition of Competences by the students is operationalized by the following items (Furco et al., 2018; Hochschule Augsburg, 2019):

"Die Service Learning-Erfahrung unterstützt die

Auseinandersetzung der Studierenden mit einem relevanten gesellschaftlichen Thema." (The service-learning experience supports students' engagement with a relevant social issue).

"Durch die Tätigkeiten im Rahmen des Projektes konnten die Studierenden persönliche Kompetenzen aufbauen." (Through the activities in the project, students were able to gain personal skills).

"Durch die Tätigkeiten im Rahmen des Projektes konnten die Studierenden soziale Kompetenzen aufbauen." (Through the activities in the project, students were able to gain social skills).

"Durch die Tätigkeiten im Rahmen des Projektes konnten die Studierenden fachliche Kompetenzen aufbauen." (Through the activities in the project, the students were able to gain technical skills).

"Durch die Tätigkeiten im Rahmen des Projektes konnten die Studierenden berufliche Kompetenzen aufbauen." (Through the activities in the project, the students were able to gain professional skills). 
5. Learning in foreign environments is operationalized by the following items (Hochschule Augsburg, 2019; Soukup, 1999; Steinke \& Fitch, 2007):

"Im Rahmen des Projekts waren die Studierenden außerhalb der Hochschule tätig (z.B. bei der Partner-Organisation vor Ort)." (As part of the project, the students were active outside the university [e.g., at the local partner organization]).

"Die Projektarbeit bot ausreichend Gelegenheit zur Begegnung der Studierenden mit der Partner-Organisation." (The project work provided ample opportunity for students to meet with the partner organization).

"Die Projektarbeit bot ausreichend Gelegenheit zur Begegnung der Studierenden mit den Service-Nehmenden." (The project work provided ample opportunity for students to meet with service recipients).

"Die Studierenden haben sich auf eine fremde Lebenswelt (z.B. Menschen mit unterschiedlichem ethnischen, kulturellen und/oder sozialen Hintergrund)

eingelassen." (Students have become involved with a foreign living environment (e.g., people from different ethnic, cultural, and/or social backgrounds).

6. Cooperation of the participants is operationalized by the following items (Hochschule Augsburg,
2019; McArthur, 2010)2:

"Die Aufgaben, Rollen und Erwartungen zwischen

Studierenden, Lehrenden und Partner-Organisationen wurden vor Projektbeginn geklärt." (The tasks, roles and expectations between students, teachers and partner organizations were clarified before the project began).

"Im Vorfeld und im Verlauf des Projekts wurden die Arbeitsschritte zwischen den Studierenden, Lehrenden und den Partner-Organisationen abgestimmt." (In the run-up to and during the project, the work steps were coordinated between the students, teachers, and the partner organizations).

"Ich als Dozierende*r habe mich an der Projektumsetzung beteiligt und meine Vorstellungen eingebracht." (As a lecturer, I participated in the implementation of the project and contributed my ideas).

"Studierende haben sich bei der Projektumsetzung beteiligt und ihre Vorstellungen eingebracht." (Students participated in the project implementation and contributed their ideas).

"Partner-Organisationen haben sich bei der Projektumsetzung beteiligt und ihre Vorstellungen

${ }^{2}$ Additional Response options here $6=$ There was no cooperation 
eingebracht." (Partner

organizations participated in the project implementation and

contributed their ideas).

"Service-Nehmende haben sich bei der Projektumsetzung beteiligt und ihre Vorstellungen eingebracht." (Service recipients participated in the project implementation and contributed their ideas).

"Die Zusamm.enarbeit mit den Studierenden war sehr gut." (The cooperation with students was very good).

"Die Zusammenarbeit mit anderen Dozierenden war sehr gut." (The cooperation with the other lecturers was very good).

"Die Zusammenarbeit mit den Partner-Organisationen war sehr gut." (The cooperation with the partner organizations was very good).

"Die Zusammenarbeitmit den Service-Nehmenden war sehr gut."(The cooperation with the service recipients was very good).

7. Reflection is operationalized by the following items (Cram, 1998; Hochschule Augsburg, 2019):

"Im Rahmen der ServiceLearning-Erfahrung wurden den Studierenden Möglichkeiten, Anreize und Raum zur Reflexion gegeben." (As part of the service-learning experience, students were provided with opportunities, incentives, and space for reflection).

"Die fachlichen Fragen, Herausforderungen und Lösungen im Projekt wurden gemeinsam mit den Studierenden reflektiert." (The professional issues, challenges and solutions in the project were reflected together with the students).

"Der organisatorische Projektverlauf wurde reflektiert." (The organizational course of the project was reflected).

"Wenn ja, mit welchen Parteien wurde der organisatorische Projektverlauf reflektiert? (Mehrfachantwortmöglich.)" (If yes, with which parties was the organizational project process reflected? (Multiple answers possible) ${ }^{3}$.

8. Supervision of students is operationalized by the following items (Astin et al., 2000; Chen et al., 2018; Hochschule Augsburg, 2019):

"Die Studierenden erhielten vor Projektbeginn Informationen, die sie auf inre Service-LearningErfahrung vorbereiteten."(Students received information prior to the start of the project that prepared

\footnotetext{
${ }^{3}$ Response options here from $1=$ with students, $2=$ with lecturers, $3=$ with partner organisations, $4=$ with service recipients
} 
them for their service-learning experience).

"Von wem wurden die Studierenden bei der Projektarbeit unterstützt und begleitet?

(Mehrfachantwortenmöglich.)"(B y whom were the students supported and accompanied during the project work? (Multiple answers possible) $^{4}$.

"Die Partner-Organisationen gewährten Zugang zu Informationen und ( $\mathrm{z} . \mathrm{B}$ personellen) Ressourcen." (Partner organizations provided access to information and (e.g., human) resources).

"Die Studierenden hätten mehr Unterstützung benötigt." (Students would have needed more support).

"Falls ja, durch: ..." (If yes, the support could have been provided through: ... $)^{5}$.

"Falls ja, wobei?" (If yes, the support could have been provided how?) ${ }^{6}$.

\section{Evaluation and quality} development is operationalized by the following items (Hochschule Augsburg, 2019;

\footnotetext{
${ }^{4}$ Response options here from $1=$ Partner organizations, $2=$ Lecturers to $3=$ Other (free answer possible)

${ }^{5}$ Response options here from $1=$ with students, $2=$ with lecturers, $3=$ with partner organizations, $4=$ with service recipients

${ }^{6}$ Free response
}

McArthur, 2010):

"Unsere Hochschule/Universität evaluiert die Projekte der Studierenden." (Our college/university evaluates students' projects) ${ }^{7}$.

"Das Erreichen der vor dem Projekt definierten Ziele wurde nach Ende des Projekts überprüft." (Achieving the objectives, which were defined before the project, was assessed after the end of the project).

"Studierende konnten stets Feedback einbringen." (Students were always able to provide feedback).

"Dozierende konnten stets Feedback einbringen." (Lecturers were always able to provide feedback).

"Partner-Organisationen konnten stets Feedback einbringen." (Partner organizations were always able to provide feedback).

"Service-Nehmende konnten stets Feedback einbringen." (Service recipients were always able to provide feedback).

"Das Feedback wurde gemeinsam mit allen Projektbeteiligten besprochen." (The feedback was discussed together with all project participants).

\footnotetext{
7 Response options here from $1=$ yes to $2=$ no and additionally $3=\mathrm{I}$ do not know
} 
10. Recognition and appreciation is operationalized by the following items (Hochschule Augsburg, 2019):

"Das Engagement und die Leistungen der Studierenden wurden angemessen gewürdigt." (The commitment and achievements of the students were appropriately acknowledged).

"Das Engagement und die Leistungen der PartnerOrganisationen wurden angemessen gewürdigt." (The commitment and achievements of the partner organizations were appropriately acknowledged).

"Das Engagement und die Leistungen der Dozierenden wurden angemessen gewürdigt." (The commitment and achievements of the lecturers were appropriately acknowledged).

"Das Engagement und die Leistungen der ServiceNehmenden wurden angemessen gewürdigt." (The commitment and achievements of the service recipients were appropriately acknowledged).

At present, the three questionnaires are being used at different universities in Germany. The statistical analyses are currently in progress.

\section{Results and discussion}

The analyses of factors and statistical parameters will show the quality of the measurement instruments and lead to further optimizations of the scales. The goal is to have an economical and useful measurement tool that reflects the aspects of service-learning and that can show potential for optimizations.

For the first time in Germany, there will be a validated evaluation tool based on the common quality criteria and developed jointly by all stakeholder groups. Through the partners in the worldwide network of service-learning, there is also the opportunity to test the use in other languages. For this purpose, an exchange with the Uniservitate partners in Poland and Ukraine is already planned.

Nevertheless, there will be cultural differences that need to be taken into account. This starts, for example, with the use of the term service-learning. The previous collaborations have shown that, on the one hand, there are difficulties in finding a term for servicelearning in the specific language of the country and, on the other hand, that various criteria cannot be translated word for word due to socialization and other linguistic and cultural contextual factors in order to obtain a high-quality measurement instrument in different languages. Thus, there are still some steps to be taken towards the implementation of a measurement instrument that allows the evaluation and further development of servicelearning projects in the local context as well as the comparison of servicelearning projects in different locations. 


\section{Conclusions}

A first version of a measurement tool for service-learning projects was presented, which needs to be further downsized by statistical testing. Nevertheless, the potential of the tool is extensive. Besides comparisons of different service-learning projects, existing projects can be further developed and optimized on the basis of the evaluation. Despite this, there is still some work to be done before the tool is available in other languages.

\section{Acknowledgements}

Special thanks for the intensive work on the quality criteria go to (alphabetical order): Claudia Bremer (Goethe University Frankfurt), Julia Derkau (University of Mannheim), Claudia Leitzmann (State Network for Civil Involvement in Bavaria), Jörg Miller (University of Duisburg-Essen), Christiane Roth (Common Mission), Christine Sattler (Halle-Saalkreis Volunteer Agency), Julia Sonnberger (University of Applied Sciences Augsburg) and Maren Schlegler and Leonie Müller of Frankfurt University of Applied Sciences for the development of the service-learning measures as well as all members in the university network.

The Higher Education Network Education through Responsibility is well aware that this practical reference framework would never have materialized if it weren't for this mutual exchange of expertise and will continue to count on the participation of servicelearning representatives in higher education and wider society.

\section{References}

Astin, A. W., Vogelsang, L. J., Ikeda, Elaine, K., \& Yee, J. A. (2000). How Service Learning Affects Students. Higher Education Research Institute. https://www.heri.ucla.edu/PDFs/HSLAS LHSLAS.PDF

Chen, T., Snell, R. S., \& Wu, C. X. (2018). Comparing the Effects of Service-Learning Versus NonserviceLearning Project Experiences on Service Leadership Emergence and Meaning Schema Transformation. Academy of Management Learning \& Education), 17(4), 474-495.

https://doi.org/10.5465/amle.2016.030 $\underline{9}$

Cram, S. B. (1998). The Impact of

Service-Learning on Moral Development and Self-Esteem of Community College Ethics Students [Doctoral theses, University of Iowa, Iowa, United States]. Institute of Education Sciences. https://eric.ed.gov/?id=ED460701

Furco, A., Hirt, L. E., Lopez, Isabel, Schulzetenberg, Anthony J., Anderson, B. N., Matthews, P. H., \& Wilder, S. O. (2018). The ServiceLearning Quality Assessment Tool (SLQAT).

Hochschule Augsburg. (Ed.). (2019). Fragebogen zur Veranstaltung.

Hochschulnetzwerk Bildung durch Verantwortung/AG Qualität. (2019). Ten Criteria - a Reference Framework for Successful Service Learning. https://www.bildung-durchverantwortung.de/wpcontent/uploads/2019/08/Qualitaetskrit 
erien_HBdV_2019_English.pdf

Hochschulnetzwerk Bildung durch Verantwortung. (2021).Chronik des Netzwerks. https://www.bildung-durchverantwortung.de/chronik/

McArthur, P. M. (2010). Case Study: Community Perspectives of a Aervice Learning Partnership Involving One School of Nursing in the Southeastern United States [PhD dissertation, University of Tennessee, Knoxville, United States].

https://trace.tennessee.edu/cgi/viewco ntent.cgi?article $=1814$ \&context $=$ utk gr addiss

Melchior, A. (1998). National Evaluation of Learn and Serve America School and Community-Based Programs: Final Report.

https://eric.ed.gov/?id=ED437575

Mishal, A., Singh, R., \& Anand, A. (2021). Development and evaluation of service-learning experience model. Journal of Public Affairs.

https://doi.org/10.1002/pa.2605

RMC Research Corporation. (2008).

Standards and Indicators for Effective Service-Learning Practice.

https://cdn.ymaws.com/www.nylc.org/r esource/resmgr/k-

$\underline{12 \mathrm{sl} \text { standards for qualit.pdf }}$

Root, S., \& Billig, S. H. (2008). Servicelearning as a promising approach to high school civic engagement. In J. S. Bixby \& J. L. Pace (Eds.), Educating democratic citizens in troubled times: Qualitative studies of current efforts (pp. 107-127). State University of New York Press.
Seifert, A., Zentner, S., \& Nagy, F. (2012). Praxisbuch Service-Learning Lernen durch Engagement an Schulen. Beltz.

Soukup, P. A. (1999). Asessing ServiceLearning in a Communication Curriculum. Institute of Education Sciences.

https://eric.ed.gov/?id=ED438569

Speck, K., \& Backhaus-Maul, H. (2007). Wissenschaftliche Evaluation des Programms "Service Learning - Schule gestaltet Gemeinwesen" im Land Sachsen-Anhalt. Potsdam/Halle.

Steinke, P., \& Fitch, P. (2007). Assessing Service-Learning. Research \& Practice in Assessment, 1(2), 1-8.

Sonnberger, J., \& Leitzmann, C. (2020). Entwicklung von QualitätskriteriendurchpartizipativeZusa mmenarbeit. In M. Hofer \& J. Derkau (Eds.), Campus und Gesellschaft (pp. 209-225). Weinheim/Basel: BeltzJuventa. Iberoamericana de Aprendizaje Servicio, 12, 45-58. DOI10.1344/RIDAS2021.12.6 